\title{
Reversion from Erythromycin Dependence in Escherichia coli: Strains Altered in Ribosomal Sub-unit Association and Ribosome Assembly
}

\author{
By DONALD G. WILD \\ Microbiology Unit, Department of Biochemistry, University of Oxford, South Parks Road, \\ Oxford OX1 $3 Q U, U K$
}

(Received 23 October 1987; revised 12 January 1988)

A mutant of Escherichia coli dependent on erythromycin for growth spontaneously gives erythromycin-independent strains with altered or missing ribosomal proteins. Strains with defects in ribosome assembly were sought and obtained from among these revertants. Two organisms in which ribosomal protein $\mathrm{L} 19$ is altered and absent respectively have $70 \mathrm{~S}$ ribosomes whose dissociation into sub-units is particularly sensitive to pressures generated during centrifuging. The mutant that lacks protein L19 also accumulates ribosome precursor particles during exponential growth as do others including mutants that lack proteins S20 or L1. These strains also show unbalanced synthesis of RNA and so will be useful in investigating both the pathways and the regulation of ribosome assembly.

\section{INTRODUCTION}

The 70S ribosome of Escherichia coli comprises three ribosomal RNAs and 52 different ribosomal proteins. From comparisons with other organisms and organelles, this is about the minimum number of components required by a functioning ribosome. The secondary structures of the ribosomal RNAs are highly conserved across bacterial species. There are also strong homologies in amino acid sequence of the individual ribosomal proteins of different bacteria so that there is, for example, little difficulty in correlating equivalent proteins from Escherichia coli and Bacillus stearothermophilus (Wittmann, 1986). Although the ribosomal RNAs are increasingly thought to be directly involved in protein synthesis (e.g. Cundliffe, 1986; Moazed \& Noller, 1987), the conservation of ribosomal proteins and the numerous studies that have implicated them in the various stages in protein synthesis show that they also have a vital role in ribosome function. However, some mutant strains of $E$. coli lack individual ribosomal proteins. These strains were obtained as organisms that had reverted to independence from dependence for growth on an antibiotic such as kasugamycin or erythromycin. (A review is by Dabbs, 1986.) Some mutants without a ribosomal protein grew slowly while others (e.g. those lacking ribosomal proteins L29 or L30) had no obvious impairment. The existence of these strains shows that all ribosomal proteins are not absolutely required for protein synthesis and emphasizes the flexibility of the ribosome.

Mutants of $E$. coli that lack a ribosomal protein have been used to help locate that protein on the surface of non-mutant ribosomal sub-units (e.g. Dabbs et al., 1981; Stöffler et al., 1984) and to explore the functions in which the protein is involved (e.g. Subramanian \& Dabbs, 1980). Little attention has been paid to organisms in which altered ribosome assembly results from absence of a ribosomal protein. This phenotype should be frequent if, as suggested by Ehrenberg et al. (1986), a major role of some ribosomal proteins is to maintain a fast kinetic pathway for assembly. A mutant lacking protein L1 oversynthesized protein L11 (Dabbs et al., 1981). This is part of the evidence (reviewed by Lindahl \& Zengel, 1986) that translation of mRNA from the L11-Ll operon is inhibited by protein $\mathrm{L} 1$; the consequences for ribosome assembly, if any, were not reported. Another revertant to erythromycin independence failed to make protein L24 
because of an ochre mutation in the $r p l X$ gene (Nishi et al., 1985). The 50S ribosomal sub-units of this mutant were as active as those from wild-type organisms in polyphenylalanine synthesis. However, in vitro, assembly of 50S sub-units was extremely slow (Herold et al., 1986), in accordance with other evidence that protein L24 is near-essential at an early stage in reconstitution (Nowotny \& Nierhaus, 1982).

Mutants lacking ribosomal proteins do not always have properties that might be predicted for them. We (Butler et al., 1980; Butler \& Wild, 1984, 1985) studied a strain of E. coli (TP28) with a mutation in the rpmB, $G$ transcription unit that halved rates of synthesis of proteins L28 and L33. The consequences of this lesion for the synthesis of other ribosomal proteins were widespread: about ten proteins were made at rates up to $75 \%$ faster than required to sustain ribosome synthesis and the excess usually degraded. Moreover, this strain accumulated large quantities of ' $47 \mathrm{~S}$ ' particles. These are unusual precursors to $50 \mathrm{~S}$ ribosomal sub-units and synthesis proceeded as though they, rather than the sub-units, were the end-product of assembly. Ribosome assembly in strains that lack proteins L28 and/or L33, rather than underproduce them, might then be expected to be even more severely restricted. However, unpublished work (by B. A. Maguire \& D. G. Wild) shows that this is not so. Mutant strains AM90 and AM108 lack ribosomal proteins L28, and L28 plus L33, respectively (Dabbs, 1979). Neither shows substantial accumulation of ribosome precursor particles, and rates of synthesis of other ribosomal proteins are less perturbed than in strain TP28. These differences are presently unexplained but, together with the other considerations above, prompted experiments that isolated phenotypic revertants from erythromycin dependence with altered ribosome assembly. The properties of some of these revertant strains are described in this paper.

\section{METHODS}

Bacteria and their growth. Experiments used E. coli strain A19 (Gesteland, 1966) and derivatives obtained as described in Results. Unless otherwise stated, organisms were grown with shaking at $37^{\circ} \mathrm{C}$ in D-broth, which contained, per litre, $10 \mathrm{~g}$ tryptone, $10 \mathrm{~g}$ yeast extract, $5 \mathrm{~g}$ glucose, $7 \mathrm{~g} \mathrm{~K}_{2} \mathrm{HPO}_{4}, 3 \mathrm{~g} \mathrm{KH}_{2} \mathrm{PO}_{4}, 500$ mg trisodium citrate. $3 \mathrm{H}_{2} \mathrm{O}$, and $100 \mathrm{mg} \mathrm{MgSO}_{4} .7 \mathrm{H}_{2} \mathrm{O}$. D-agar was the same medium solidified with $1.5 \%(\mathrm{w} / \mathrm{v})$ agar. Erythromycin (from Boehringer-Mannheim) was added to media from a filter-sterilized solution (usually $10 \mathrm{mg}$ $\left.\mathrm{ml}^{-1}\right)$ in $50 \%(\mathrm{v} / \mathrm{v})$ ethanol.

Preparation of extracts and density-gradient centrifugation. Organisms grown in 10-25 ml D-broth to $\mathrm{OD}_{450} \sim 0.5$ were harvested, washed with 2-5 $\mathrm{ml} \mathrm{THMK}$ buffer $(10 \mathrm{mM}$-Tris/ $\mathrm{HCl}, \mathrm{pH} 7 \cdot 4,10 \mathrm{mM}$-magnesium acetate, $100 \mathrm{mM}$ $\mathrm{KCl}$ ) and broken in a French pressure cell. Portions of extracts (usually $100 \mu \mathrm{l}$ ) were layered onto $15-30 \%(\mathrm{w} / \mathrm{w}$ ) sucrose gradients made in THMKSp buffer (THMK buffer containing $1 \mathrm{mM}$-spermidine. $\mathrm{HCl}$ ) and centrifuged at $4{ }^{\circ} \mathrm{C}$ usually for $2.5 \mathrm{~h}$ at 50000 r.p.m. $\left(237000 \mathrm{~g}_{\text {av }}\right.$ ) in a Spinco SW 55Ti rotor. (Other rotors and conditions of centrifuging are noted in the text.) Gradients were collected through an Isco density-gradient fractionator. For some experiments, $\left[{ }^{14} \mathrm{C}\right]$ uracil and/or $\left[{ }^{3} \mathrm{H}\right]$ uracil were added to the growth medium; then, after centrifuging, about 50 three-drop fractions were collected and assayed for radioactivity (Markey \& Wild, 1976).

Two-dimensional gel electrophoresis of ribosomal proteins. Organisms were grown in $300 \mathrm{ml} \mathrm{D}$-medium to late exponential phase, harvested, washed with TMKSH buffer $(10 \mathrm{mM}$-Tris/ $\mathrm{HCl}, \mathrm{pH} 7 \cdot 4,15 \mathrm{mM}$-magnesium acetate, $60 \mathrm{mM}-\mathrm{KCl}, 7 \mathrm{mM}$-2-mercaptoethanol) and resuspended in $8 \mathrm{ml}$ of this buffer. An extract, made using a French pressure cell, was clarified ( $15 \mathrm{~min} ; 25000$ r.p.m.; Spinco Type 40 rotor) and the supernatant then centrifuged ( $2 \mathrm{~h}$;

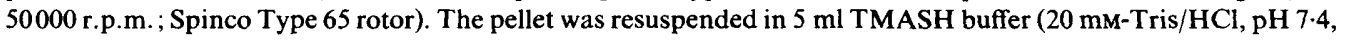
$10 \mathrm{~mm}$-magnesium acetate, $500 \mathrm{mM}-\mathrm{NH}_{4} \mathrm{Cl}, 14 \mathrm{mM}$-2-mercaptoethanol), underlayered with $3 \mathrm{ml}$ TMASH buffer containing $1 \cdot 1 \mathrm{M}$-sucrose and centrifuged for $16 \mathrm{~h}$ at 40000 r.p.m. (Spinco Type 50 rotor). The pellet of ribosomes was dissolved in $1 \mathrm{ml} 8 \mathrm{M}$-urea containing $1 \%(\mathrm{v} / \mathrm{v}) 2$-mercaptoethanol. The ribosomal proteins were extracted with acetic acid according to Hardy (1975), precipitated with acetone (Barritault et al., 1976), dried in vacuo and dissolved in $500 \mu 18 \mathrm{M}$-urea, $1 \% 2$-mercaptoethanol. Samples were analysed in the 'standard' two-dimensional electrophoresis system of Kenny et al. (1979) without alkylation of proteins. Some samples were also run with SDS/urea gels (Madjar et al., 1979) in the second dimension. Gels were stained for about $2 \mathrm{~h}$ with Coomassie Blue R250 $(0.1 \%)$ in destaining solution (methanol/water/acetic acid, $5: 5: 1$, by vol.).

RESULTS

\section{Isolation of an erythromycin-dependent strain and revertants to independence}

The erythromycin-dependent strain 103 was one of several isolated by an antibiotic-underlay method (Dabbs, 1979). For this, E. coli strain A19, suspended $\left(\mathrm{OD}_{450} \sim 0.5\right)$ in buffer $(50 \mathrm{~mm}-$ 


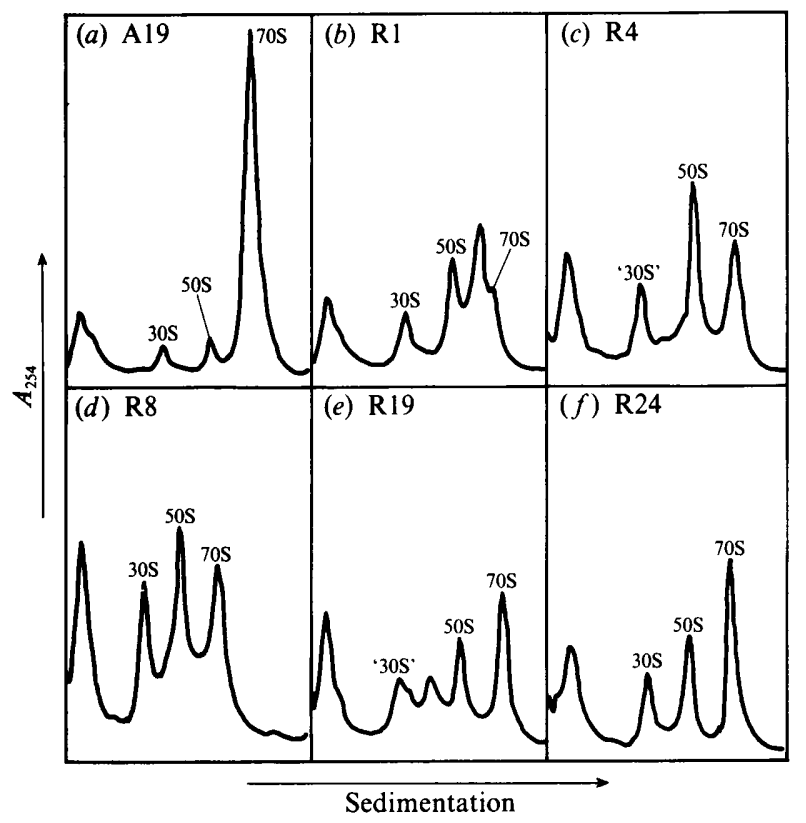

Fig. 1. Sedimentation profiles of ribosomal particles from wild-type and mutant strains after sucrosedensity-gradient centrifugation under 'standard' conditions (see Methods). Extracts were made from (a) strain A19; (b) strain R1 (revertant no. 1); (c) strain R4; $(d)$ strain R8; $(e)$ strain R19; $(f)$ strain R24.

Tris, $50 \mathrm{~mm}$-maleic acid; $\mathrm{pH}$ brought to 6.2 with $5 \mathrm{M}-\mathrm{NaOH}$ ) containing $200 \mu \mathrm{g} N$-methyl- $N^{\prime}$ nitro- $N$-nitrosoguanidine (NTG) $\mathrm{ml}^{-1}$ was incubated for $20 \mathrm{~min}$ at $37^{\circ} \mathrm{C}$. Survival was about $50 \%$. Washed organisms were spread on D-agar ( $\sim 25 \mathrm{ml}$ agar per plate) and incubated for $3 \mathrm{~h}$ at $37^{\circ} \mathrm{C}$. The agar was then underlayered with $0.15 \mathrm{ml}(5 \mathrm{mg})$ erythromycin. The antibiotic was allowed to diffuse for $3 \mathrm{~d}$ at $4{ }^{\circ} \mathrm{C}$. Plates were then incubated for $2 \mathrm{~d}$ at $37^{\circ} \mathrm{C}$ and colonies patched with sterile toothpicks onto D-agar without and with $200 \mu \mathrm{g}$ erythromycin $\mathrm{ml}^{-1}$. About $0 \cdot 1-0.5 \%$ of resistant strains were also dependent on erythromycin for growth. One of these, strain 103, grew exponentially in D-medium containing 50,100 or $200 \mu \mathrm{g}$ erythromycin $\mathrm{ml}^{-1}$ with generation times at $37^{\circ} \mathrm{C}$ of 75,80 and 100 min respectively but did not grow in the absence of erythromycin. Strain A19 had a generation time of 25 min in D-medium; its growth was severely inhibited by $50 \mu \mathrm{g}$ erythromycin $\mathrm{ml}^{-1}$.

Strain 103 (but not strain A19) grew on D-agar containing 100 or $200 \mu \mathrm{g}$ erythromycin $\mathrm{ml}^{-1}$. On D-agar without erythromycin about $0.0005 \%$ of organisms spread gave colonies of varied sizes. A selection of these 'revertants' was purified by restreaking and then grown in D-medium to $\mathrm{OD}_{450} \sim 0.5$. Extracts were made in THMKSp buffer and centrifuged through sucrose gradients in this buffer. Under these conditions the sedimentation profile of strain A19 showed native $30 \mathrm{~S}$ and $50 \mathrm{~S}$ sub-units to be present in small quantities relative to $70 \mathrm{~S}$ ribosomes (Fig. $1 \mathrm{a}$ ); the profile of strain 103 (after growth in D-medium containing $100 \mu \mathrm{g}$ erythromycin $\mathrm{ml}^{-1}$ ) was similar but with rather more material in the region of $30 \mathrm{~S}$ sub-units (e.g. Fig. $3 a, b$ ). Most (about $90 \%$ of) revertant strains gave profiles similar to that of strain A19. Some did not. For example, revertant strain no. 1 ( $\mathrm{R} 1$ hereafter) had a profile (Fig. $1 b$ ) in which the most prominent component has a sedimentation coefficient of about $60 \mathrm{~S}$ and lay between the $50 \mathrm{~S}$ sub-units and the few $70 \mathrm{~S}$ ribosomes. With strain R4 (Fig. 1 c), there were also few $70 \mathrm{~S}$ ribosomes; the major ribonucleoprotein component was in the approximate position of $50 \mathrm{~S}$ sub-units and there was also an excess of '30S' material. The profile of strain R8 (Fig. 1d) also showed few 70S ribosomes; most ribonucleoprotein was in the position expected of ribosomal sub-units. Rather similarly, strain R24 (Fig. $1 f$ ) had an excess of material in the region of sub-units; so did strain 


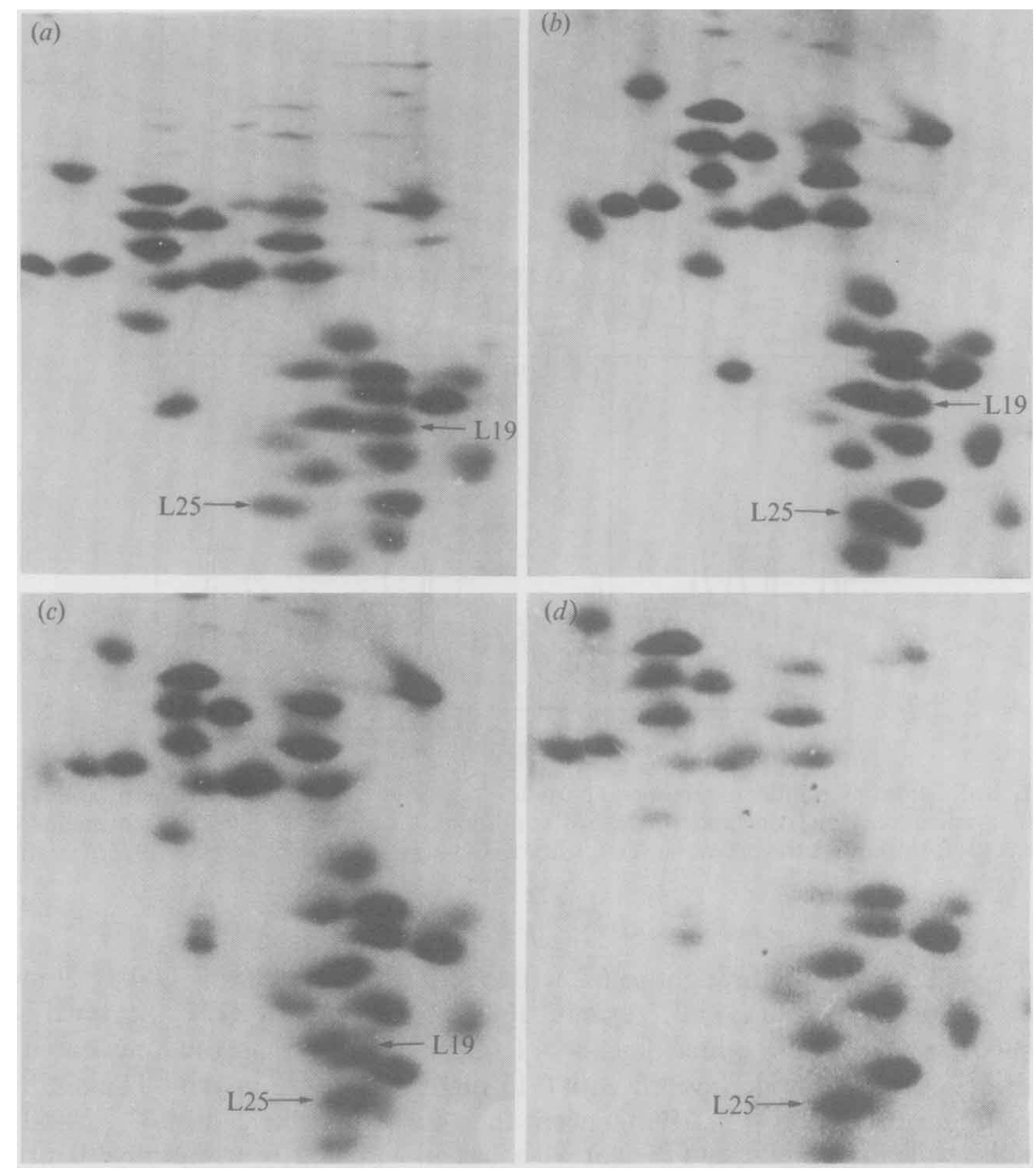

Fig. 2. Two-dimensional gel electrophoresis of ribosomal proteins from wild-type and mutant strains. (a) Strain A19; (b) strain 103; (c) strain R1; (d) strain R8.

R19 (Fig. $1 e$ ) although the profile of the latter had an additional major '40S' component. Thus some revertant strains re-acquire the ability to grow without erythromycin at the expense of abnormalities in ribosome metabolism. In these cases at least, 'reversion' is unlikely to involve reversal of the mutation(s) that created the dependence of strain 103 on the antibiotic.

\section{Ribosomal proteins of dependent and revertant strains}

Strains A19, 103 and several revertants were grown in D-medium and their ribosomal proteins (obtained as in Methods) examined by two-dimensional gel electrophoresis. The standard system resolved about 48 of the 52 ribosomal proteins; these were identified with the key provided by Madjar et al. (1979). Comparison of strains A19 and 103 (Fig. $2 a, b$ ) shows that in the latter the mobility of protein L25 was greater in both dimensions. The second dimension of the 'standard' electrophoresis separates partially by molecular mass. When this was replaced by an SDS/urea gel, the mobility of protein L25 from strain 103 was not distinguishable from that from strain A19. Protein L25 from strain 103 has thus gained in positive charge rather than decreased in molecular mass. The altered L25 was also apparent in all revertant strains examined. Some of the latter had additional changes. In strain R1, the mobility of protein L19 was reduced in the first dimension and increased in the second (Fig. 2c); in strain R8, this 


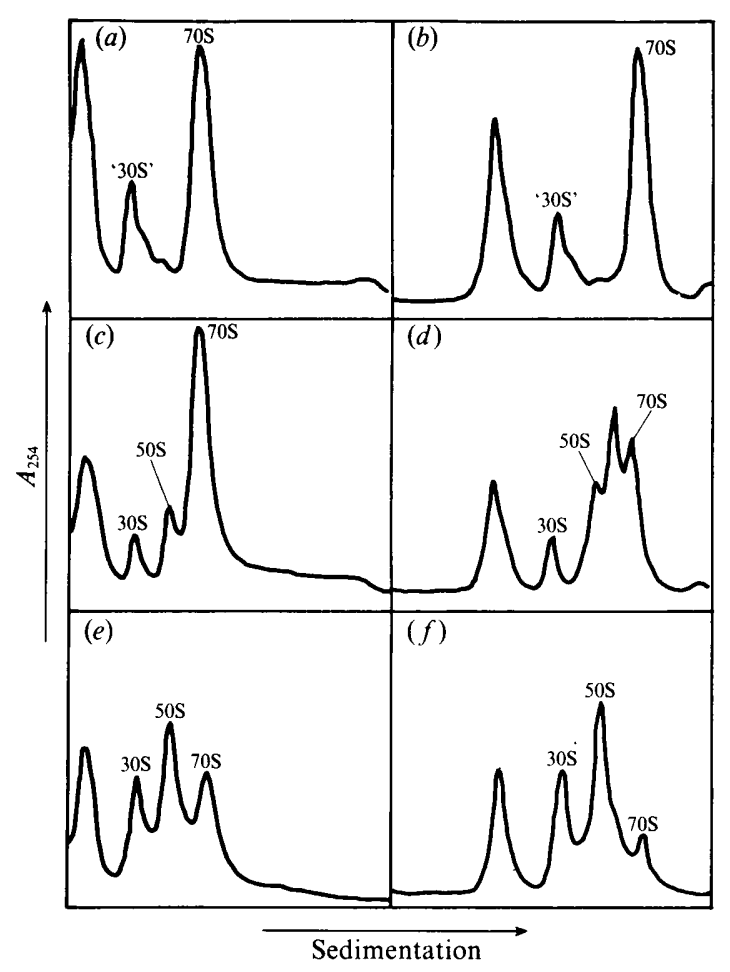

Fig. 3. Effect of pressure on sedimentation profiles. An extract of strain 103 was made in THMKSp

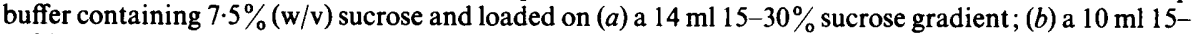
$30 \%$ sucrose gradient that was then overlayered with $4 \mathrm{ml}$ THMKSp buffer. Gradients $(c)$ and $(d)$ were as $(a)$ and $(b)$ respectively but used an extract from strain R1. Gradients $(e)$ and $(f)$ were as $(a)$ and $(b)$ respectively but used an extract from strain R8. Centrifuging was for $2.5 \mathrm{~h}$ at 40000 r.p.m. in a Spinco SW 40Ti rotor.

protein was missing from its usual position and was not detected elsewhere (Fig. 2d). The set of proteins from strain R4 lacked protein S20, while strain R24 had no protein L1. Because some proteins are extracted rather variably and/or stain poorly, absences were confirmed by electrophoresis of at least three separate preparations of proteins from each revertant. 'Absence' does not distinguish between failure of synthesis and presence in some grossly altered and undetected form. Not all revertants showed alterations additional to that in protein L25; none was detected in strain R19, in which ribosome assembly was abnormal (Fig. $1 e$ ), or in strains R10 and R15, which had sedimentation profiles similar to that of strain A19.

\section{Pressure-sensitivity of ribosomes from revertant strains}

Revertant R1 grew faster (generation time about $40 \mathrm{~min}$ ) than other revertants (Fig. $7 a$ ) but gave a sedimentation profile with a preponderance of ' $60 \mathrm{~S}$ ' material and few $70 \mathrm{~S}$ ribsomes (Fig. $1 b$ ). This suggested that the $70 \mathrm{~S}$ ribosomes of strain $\mathrm{R} 1$ were dissociating during centrifuging at the hydrostatic pressures generated under 'standard' conditions (50000 r.p.m.; 2.5 h). Extracts centrifuged more slowly ( 20000 r.p.m.) for longer $(15 \mathrm{~h}$ ) gave a profile (not shown) in which $70 \mathrm{~S}$ ribosomes were now the major component; $70 \mathrm{~S}$ ribosomes also predominated when $20 \mathrm{~mm}$ $\mathrm{Mg}^{2+}$ replaced the $10 \mathrm{mM}-\mathrm{Mg}^{2+}$ of THMKSp buffer. Effects of hydrostatic pressure were shown directly. For this, extracts of strains 103 and R1 were each layered on two sucrose gradients made with $14 \mathrm{ml}$ and $10 \mathrm{ml}$ of THMKSp buffer respectively. The $10 \mathrm{ml}$ gradients were then overlayed with $4 \mathrm{ml}$ of buffer. Centrifuging was for $2.5 \mathrm{~h}$ at 40000 r.p.m. in the SW 40Ti rotor. Under these conditions the profile of strain R1 (but not strain 103) showed 60S material only at the higher pressure generated by the buffer overlay (Fig. 3). The defect in strain R1 was localized 


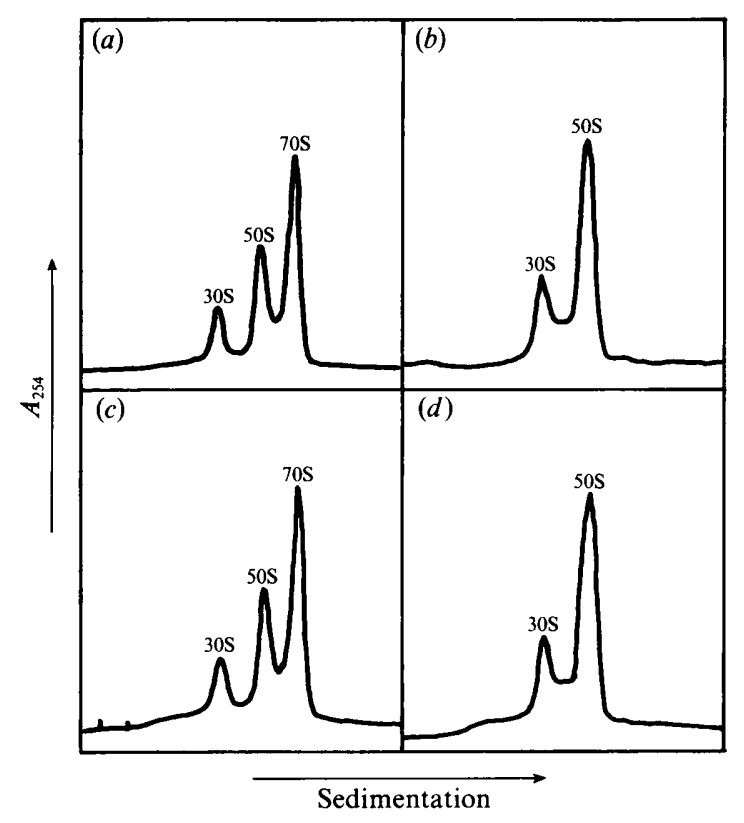

Fig. 4. Re-association of ribosomal sub-units. Extracts of strains A19 and R1, made in TLMKSH buffer (10 mM-Tris/HCl, pH 7.4, 2 mM-magnesium acetate, $100 \mathrm{~mm}-\mathrm{KCl}, 7 \mathrm{~mm}$-2-mercaptoethanol), were centrifuged through sucrose gradients in this buffer and fractions containing $30 \mathrm{~S}$ or $50 \mathrm{~S}$ ribosomal sub-units pooled separately. Magnesium acetate (1 M) was added to each pool (final concn $10 \mathrm{~mm}$ ). Mixtures (total vol. $150 \mu \mathrm{l} ; A_{254}$ of $50 \mathrm{~S}$ and $30 \mathrm{~S}$ sub-units in a ratio of $2: 1$ ) were made, diluted with 150 $\mu 1$ THMKSH buffer (THMK buffer $+7 \mathrm{mM}-2$-mercaptoethanol) and incubated at $37^{\circ} \mathrm{C}$ for $15 \mathrm{~min}$. Each mixture was loaded on a $15-30 \%$ sucrose gradient $(10 \mathrm{ml})$ in THMKSH buffer and overlayered with $4 \mathrm{ml}$ of this buffer. Centrifuging was for $4.5 \mathrm{~h}$ at 30000 r.p.m. in the SW40 Ti rotor. (a) $50 \mathrm{~S}$ subunits from strain A19, 30S sub-units from strain R1; (b) 30S sub-units from strain A19, 50S sub-units from strain R1; (c) 30S and 50S sub-units from strain A19; (d) 30S and 50S sub-units from strain R1.

to the 50S ribosomal sub-units. Extracts of strains A19 and R1 were made and centrifuged through gradients in buffer containing $2 \mathrm{mM}^{-\mathrm{Mg}^{2+}}$ and in which $70 \mathrm{~S}$ ribosomes dissociate to sub-units. The latter were isolated and, after increasing the $\mathbf{M g}^{2+}$ concentration to $10 \mathrm{mM}$, mixed in approximately equimolar proportions. Mixtures were activated (Zamir et al., 1974) at $37^{\circ} \mathrm{C}$ for $15 \mathrm{~min}$ and then centrifuged (SW 41 rotor; $4.5 \mathrm{~h} ; 30000$ r.p.m.) through $10 \mathrm{ml}$ sucrose gradients with an overlayer of $4 \mathrm{ml}$ buffer. When the $50 \mathrm{~S}$ sub-units were from strain A19, about half the sub-units associated to form $70 \mathrm{~S}$ ribosomes (Fig. $4 a, c$ ), irrespective of the source of the $30 \mathrm{~S}$ sub-units; when the $50 \mathrm{~S}$ sub-units were from strain R1, there was no association (Fig. $4 b, d$ ).

The sedimentation profiles of strains R4, R8 and R24 obtained under 'standard' conditions (Fig. $1 c, d, f$ ) showed few $70 \mathrm{~S}$ ribosomes. This could result from extensive dissociation to subunits during centrifuging. However, in contrast to strain R1, the profiles given by strains R4 and R24 did not alter when extracts were centrifuged at low rather than high speed or at different pressures or at $20 \mathrm{mM}-\mathrm{Mg}^{2+}$. Extracts of revertant strain $\mathbf{R} 8$ also gave very similar profiles at 10 and $20 \mathrm{mM}-\mathrm{Mg}^{2+}$. However, the profiles of extracts centrifuged at low speed showed rather more $70 \mathrm{~S}$ ribosomes and, when pressures during centrifuging were increased by an overlayer of buffer, dissociation of $70 \mathrm{~S}$ ribosomes into ribosomal sub-units (rather than to ' $60 \mathrm{~S}$ ' material as in strain $\mathrm{R} 1$ ) was virtually complete (Fig. $3 e, f$ ).

Thus strain $\mathrm{R} 1$, with an altered ribosomal protein $\mathrm{L} 19$, has a normal complement of $70 \mathrm{~S}$ ribosomes that are prone to 'dissociate' to $60 \mathrm{~S}$ material during centrifuging. Strain R8 lacks L19 and has rather few $70 \mathrm{~S}$ ribosomes. These are also pressure sensitive and possibly more so than those of strain R1. 


\section{Ribosome precursor particles in revertant strains}

Components that have sedimentation coefficients of $50 \mathrm{~S}$ or less in profiles or revertant strains could be ribosome precursor particles (as is likely with the '40S' material of strain R19) and/or ribosomal sub-units. Distinction between precursors and sub-units is often not obvious because sedimentation properties can be very similar (Butler et al., 1980). Moreover, in strains that lack ribosomal proteins the sedimentation of the ribosomal sub-units may be altered. These possibilities were examined in two revertant strains, R4 and R8.

Strain $\mathrm{R4} .{ }^{3} \mathrm{H}$-labelled $70 \mathrm{~S}$ ribosomes from strain $\mathrm{R} 4$ were isolated from sucrose gradients and mixed with ${ }^{14} \mathrm{C}$-labelled $70 \mathrm{~S}$ ribosomes from strain A19. The mixture was dialysed in buffer containing $2 \mathrm{mM}-\mathrm{Mg}^{2+}$ and sub-units were displayed by gradient centrifuging. The $30 \mathrm{~S}$ (but not the 50S) sub-units from strain R4 sedimented rather less far than those of strain A19 (Fig. 5a), presumably due to the absence of protein S20. This is an interface protein (synonymous with L26) found associated with either sub-unit; on this evidence, it is better regarded as a small subunit protein. ${ }^{3} \mathrm{H}$ - and ${ }^{14} \mathrm{C}$-labelled extracts of strains $\mathrm{R} 4$ and A19 in THMKSp buffer were also mixed and centrifuged. The ' 30 ' ' material from strain R4 sedimented less far than the native 30 S ribosomes of strain A19 (Fig. $5 b$ ). However, the following experiment showed that this was not due to differences in sedimentation properties of the $30 \mathrm{~S}$ ribosomal sub-units of the two strains. Strain R4 was labelled with both $\left[{ }^{3} \mathrm{H}\right]$ - and $\left[{ }^{14} \mathrm{C}\right]$ uracil during growth for three generations. The organisms were collected by centrifuging and resuspended in medium with only $\left[{ }^{3} \mathrm{H}\right]$ uracil (at the same specific activity as before resuspension). Growth resumed without lag and there was no loss of ${ }^{14} \mathrm{C}$ radioactivity insoluble at $0{ }^{\circ} \mathrm{C}$ in trichloroacetic acid. Extracts made at intervals were centrifuged through sucrose gradients; Fig. $5(c, d)$ shows sedimentation profiles before and 1.55 generations after removal of ${ }^{14} \mathrm{C}$ radioactivity. At the time of resuspension, the profiles of ${ }^{3} \mathrm{H}$ and ${ }^{14} \mathrm{C}$ material were identical (Fig. $5 c$ ). The ${ }^{3} \mathrm{H}$ profile showed no significant change during subsequent growth. However there was a marked loss of ${ }^{14} \mathrm{C}$ radioactivity from $30 \mathrm{~S}$ material (Fig. $5 d$ ). Analysis of the redistribution of ${ }^{14} \mathrm{C}$ radioactivity in all samples taken showed that this loss was accompanied by an increase in the normalized specific activity of $70 \mathrm{~S}$ ribosomes (Fig. $5 e$ ). The interpretation is that much of the $30 \mathrm{~S}$ material in strain $\mathrm{R} 4$ comprises a precursor(s) to $30 \mathrm{~S}$ ribosomal sub-units: maturation and combination with $50 \mathrm{~S}$ sub-units gives $70 \mathrm{~S}$ ribosomes. There is no large change in ${ }^{14} \mathrm{C}$ radioactivity in native $50 \mathrm{~S}$ ribosomes since these can exchange with the $50 \mathrm{~S}$ sub-units of $70 \mathrm{~S}$ ribosomes. Fig. $5(e)$ also shows that the ${ }^{14} \mathrm{C}$ radioactivity in the minor ' $40 \mathrm{~S}$ ' component visible in profiles (e.g. Fig. $1 c$ ) rapidly decays as expected for a precursor particle.

Strain R8. No differences in sedimentation between the $30 \mathrm{~S}, 50 \mathrm{~S}$ or $70 \mathrm{~S}$ components of strains R8 and A19 were detected when extracts, made in THMKSp buffer and labelled with $\left[{ }^{3} \mathrm{H}\right]-$ and $\left[{ }^{14} \mathrm{C}\right]$ uracil respectively, were mixed and sedimented through sucrose gradients at low speed (SW 50.1 rotor; 20000 r.p.m.; 15.5 h). However, in TLMK buffer (see legend to Fig. 5), in which $70 \mathrm{~S}$ ribosomes dissociate to sub-units, the $50 \mathrm{~S}$ material from strain R8 consistently sedimented rather more slowly than the $50 \mathrm{~S}$ ribosomal sub-units of strain A19, presumably as a consequence of the lack of protein L19. Strain R8 was grown for three generations with both $\left[{ }^{3} \mathrm{H}\right]-$ and $\left[{ }^{14} \mathrm{C}\right]$ uracil present. As in the comparable experiment with strain $\mathrm{R} 4$, organisms were collected and resuspended in medium with only $\left[{ }^{3} \mathrm{H}\right]$ uracil added. Growth resumed without lag or loss of acid-insoluble ${ }^{14} \mathrm{C}$ radioactivity. Fig. $6(a, b)$ shows the sedimentation profiles immediately after removal of ${ }^{14} \mathrm{C}$ radioactivity and 1.75 generations later, when the ${ }^{3} \mathrm{H}$ profile has changed little but the ${ }^{14} \mathrm{C}$ profile shows an increase in the proportion of $70 \mathrm{~S}$ ribosomes at the expense of both $30 \mathrm{~S}$ and $50 \mathrm{~S}$ components. Consideration of the redistribution in all samples taken (Fig. $6 \mathrm{c}$ ) shows that these changes are essentially complete within a generation. This is consistent with the formation of $70 \mathrm{~S}$ ribosomes from precursors to both ribosomal sub-units but with an excess of sub-units present after maturation is complete. 

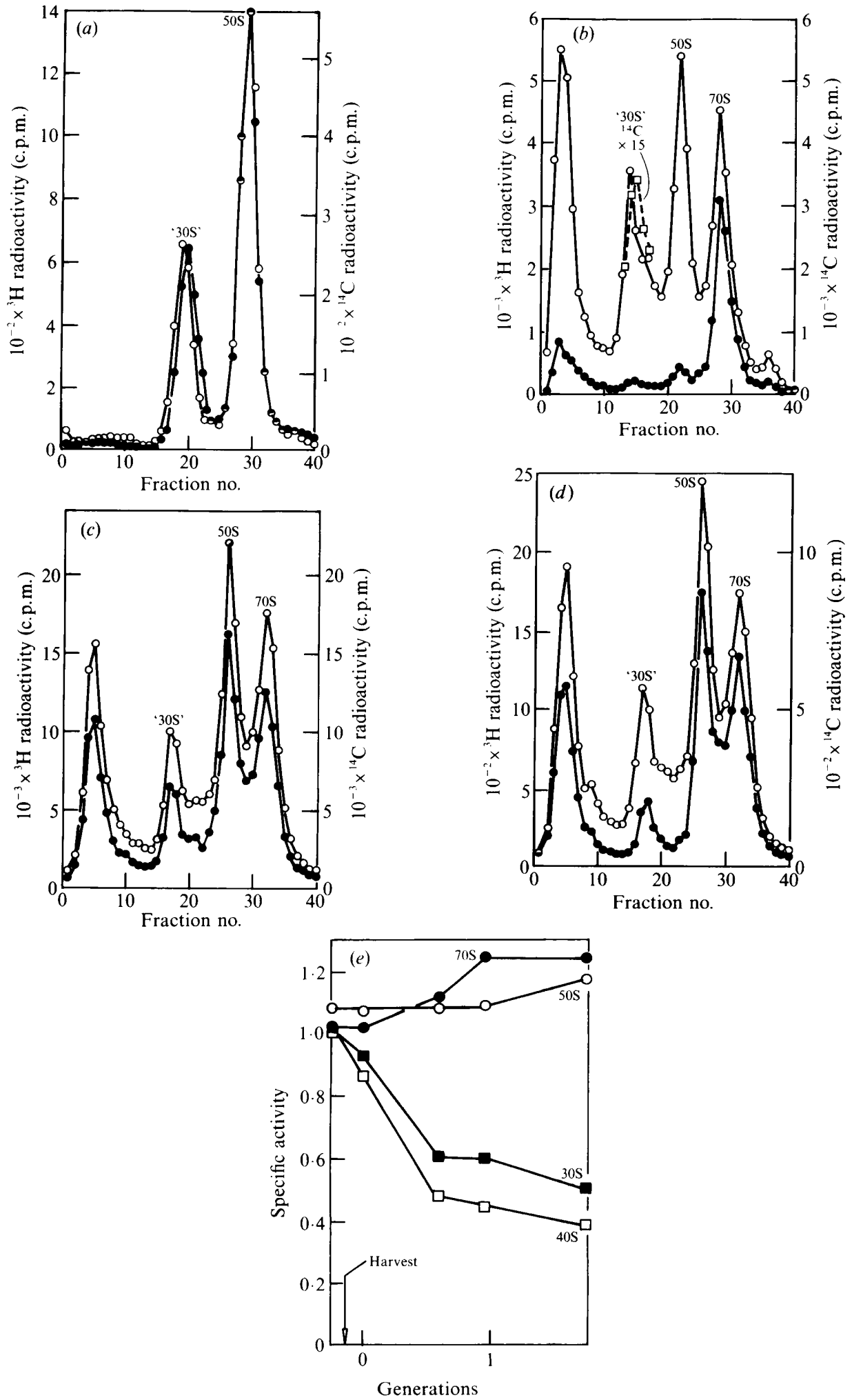

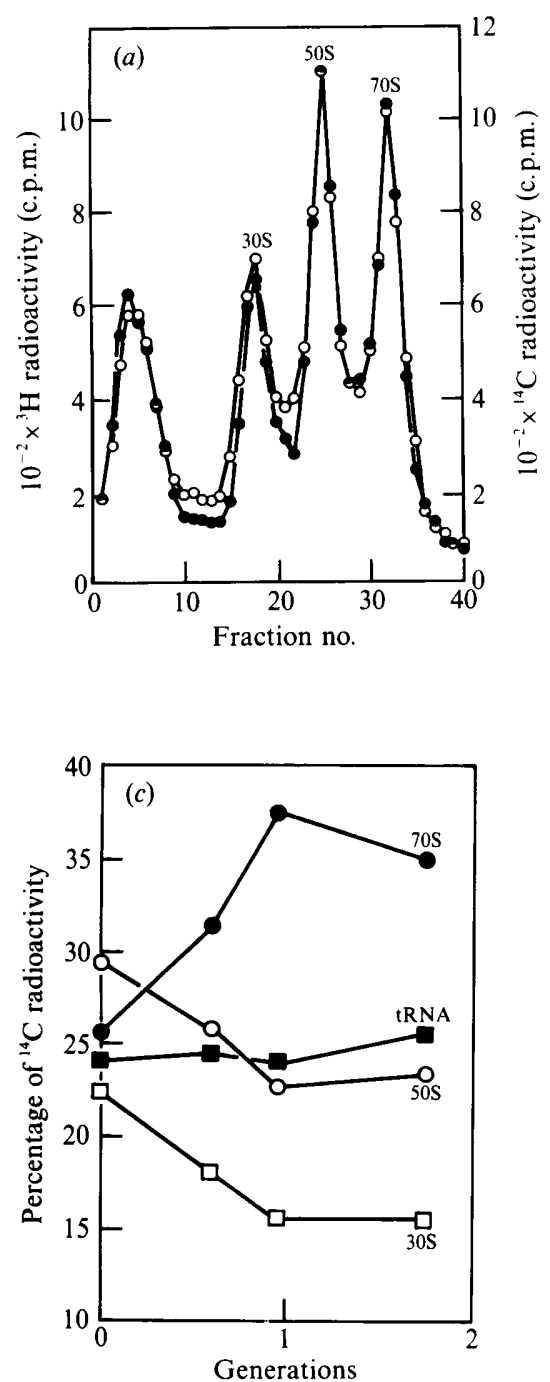

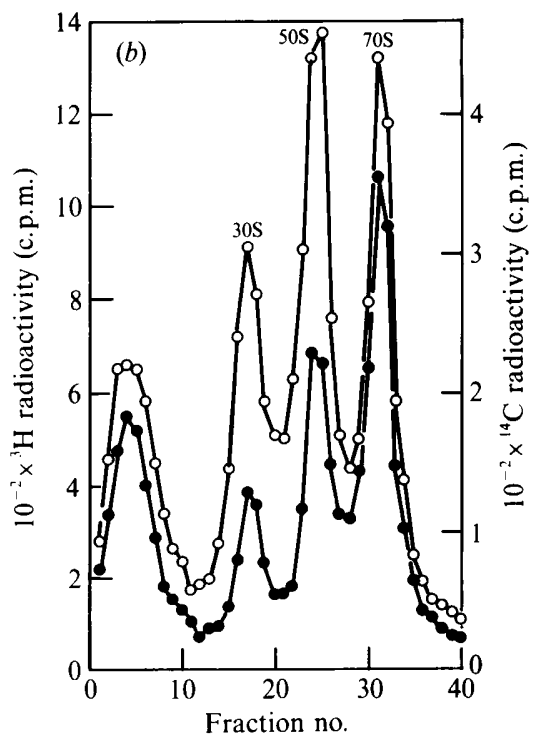

Fig. 6. Metabolic fate of ribonucleoproteins in strain R8. Strain R8 was grown from $\mathrm{OD}_{450}$ $\sim 0.025$ in D-broth containing $\left[{ }^{3} \mathrm{H}\right]$ uracil $(0.45$ $\mu \mathrm{Ci} \mathrm{ml} l^{-1} ; 16.65 \mathrm{kBq} \mathrm{ml}^{-1}$ ) and $\left[{ }^{14} \mathrm{C}\right] \mathrm{uracil}$ $\left(0.06 \mu \mathrm{Ci} \mathrm{ml}^{-1} ; 2 \cdot 2 \mathrm{kBq} \mathrm{ml}^{-1}\right)$. At $\mathrm{OD}_{450} 0.4$, a sample $(50 \mathrm{ml})$ was harvested, washed on the centrifuge with $50 \mathrm{ml} \mathrm{D}$-broth at $0^{\circ} \mathrm{C}$ (no added radioactivity) and resuspended at $37^{\circ} \mathrm{C}$ in $200 \mathrm{ml} \mathrm{D}$-broth with only $\left[{ }^{3} \mathrm{H}\right]$ uracil $(0 \cdot 45$ $\mu \mathrm{Ci} \mathrm{ml}^{-1}$ ) added. Samples were taken at intervals and portions of extracts, made in THMKSp buffer, centrifuged through sucrose gradients in this buffer for $15.5 \mathrm{~h}$ at 20000 r.p.m. (SW55 Ti rotor). (a) The sample taken immediately after resuspension; $(b)$ that taken 1.75 generations later. $\mathrm{O},{ }^{3} \mathrm{H}$ radioactivity; , ${ }^{14} \mathrm{C}$ radioactivity. (c) Distribution of ${ }^{14} \mathrm{C}$ radioactivity in areas of the gradients in all samples; 'tRNA' includes all material with a sedimentation coefficient less than about $20 \mathrm{~S}$.

Fig. 5 (on facing page). Ribonucleoproteins in strain R4. (a) Strains A19 and R4 were grown from $\mathrm{OD}_{450} \sim 0.025$ to 0.5 in D-broth containing respectively $0.1 \mu \mathrm{Ci}(3.7 \mathrm{kBq})\left[{ }^{14} \mathrm{C}\right]$ uracil $\mathrm{ml}^{-1}$ and $1 \mu \mathrm{Ci}(37$ $\mathrm{kBq})\left[{ }^{3} \mathrm{H}\right]$ uracil $\mathrm{ml}^{-1}$. Extracts made in THMKSp buffer were mixed and centrifuged for $15 \mathrm{~h}$ at 21000 r.p.m. through sucrose gradients in this buffer (SW27 rotor). Fractions containing $70 \mathrm{~S}$ ribosomes were pooled, dialysed for $4 \mathrm{~h}$ against TLMK buffer $(10 \mathrm{mM}$-Tris/ $\mathrm{HCl}, 2 \mathrm{~mm}$-magnesium acetate, $100 \mathrm{mM}$ $\mathrm{KCl})$ and a portion centrifuged $(2.5 \mathrm{~h} ; 50000$ r.p.m.; $\mathrm{SW} 55 \mathrm{Ti}$ rotor) through a sucrose gradient in this buffer. $\mathrm{O},{ }^{3} \mathrm{H}$ radioactivity;,${ }^{14} \mathrm{C}$ radioactivity. (b) Strains $\mathrm{A} 19$ and $\mathrm{R} 4$ were grown as in $(a)$. Extracts of each were made in THMKSp buffer, mixed and centrifuged (2.5 h; 50000 r.p.m. SW55 Ti rotor) through a sucrose gradient in this buffer. $\mathrm{O},{ }^{3} \mathrm{H}$ radioactivity;,${ }^{14} \mathrm{C}$ radioactivity; $\square,{ }^{14} \mathrm{C}$ radioactivity on an expanded scale $(\times 15)$. For $(c),(d)$ and $(e)$, strain $\mathrm{R} 4$ was grown from $\mathrm{OD}_{450} \sim 0.025$ in D-broth containing [ $\left.{ }^{3} \mathrm{H}\right]$ uracil $\left(0.45 \mu \mathrm{Ci} \mathrm{ml}^{-1} ; 16.65 \mathrm{kBq} \mathrm{ml}^{-1}\right)$ and $\left[{ }^{14} \mathrm{C}\right]$ uracil $\left(0.06 \mu \mathrm{Ci} \mathrm{ml}^{-1} ; 2 \cdot 2\right.$ $\left.\mathrm{kBq} \mathrm{ml}{ }^{-1}\right)$. At $\mathrm{OD}_{450} 0 \cdot 4$, a sample $(20 \mathrm{ml})$ was taken for an extract and the remainder $(50 \mathrm{ml})$ harvested and resuspended at $37^{\circ} \mathrm{C}$ in $200 \mathrm{ml} \mathrm{D}$-broth with only $\left[{ }^{3} \mathrm{H}\right]$ uracil $\left(0.45 \mu \mathrm{Ci} \mathrm{ml}^{-1}\right)$ added. Samples were taken at intervals and extracts in THMKSp buffer centrifuged $(2.5 \mathrm{~h} ; 50000$ r.p.m.; SW55 Ti rotor). (c) The sample taken immediately after resuspension; $(d)$ that taken 1.55 generations later. $O,{ }^{3} \mathrm{H}$ radioactivity;,${ }^{14} \mathrm{C}$ radioactivity. (e) Specific activity of the components in all the samples, obtained by dividing the ratio ${ }^{14} \mathrm{C}$ radioactivity $/{ }^{3} \mathrm{H}$-radioactivity in the peak fraction corresponding to each component by the corresponding ratio in the peak of tRNA. 


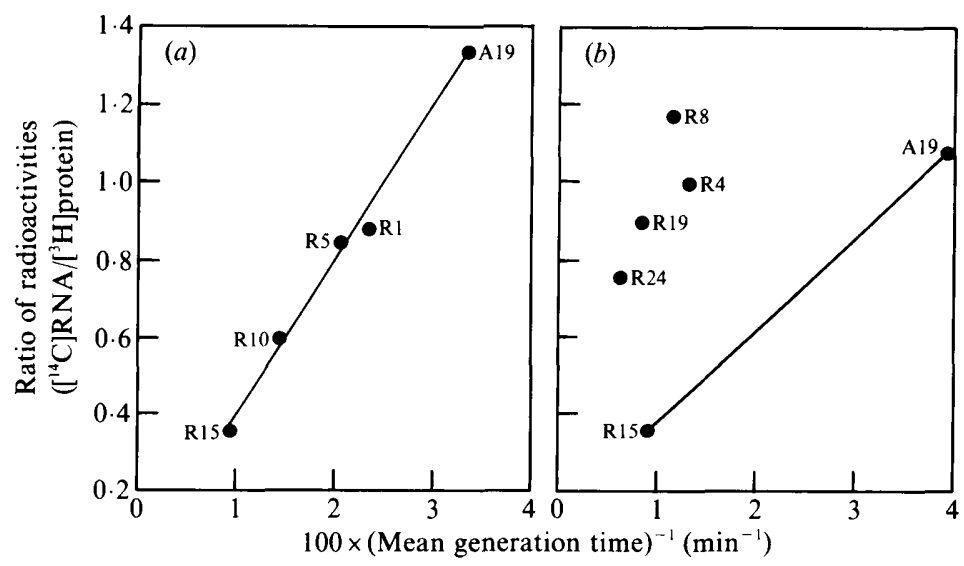

Fig. 7. RNA content of revertant strains. For $(a)$, the strains indicated were inoculated $\left(\mathrm{OD}_{450} \sim 0.02\right)$ into portions of the same batch of D-broth with $\left[{ }^{3} \mathrm{H}\right] \mathrm{lysine}\left(2 \cdot 7 \mu \mathrm{Ci} \mathrm{ml}^{-1} ; 99.9 \mathrm{kBq} \mathrm{ml}^{-1}\right)$ and $\left[{ }^{14} \mathrm{C}\right]$ uracil $\left(0.01 \mu \mathrm{Ci} \mathrm{ml}^{-1} ; 0.4 \mathrm{kBq} \mathrm{ml}^{-1}\right)$ added. At $\mathrm{OD}_{450} 0.5$, four samples $(0.5 \mathrm{ml})$ were taken from each culture for the estimation of radioactivities insoluble at $0{ }^{\circ} \mathrm{C}$ in $5 \%(w / v)$ trichloroacetic acid. (b) A second experiment with the strains shown.

\section{RNA content of revertant strains}

Several revertants to erythromycin independence thus contain 'extra' ribonucleoprotein either as ribosomal sub-units or ribosome precursor particles or both. This excess could be reflected in a high RNA content of organisms; or, the total RNA content of revertants might be that characteristic of their rates of growth. Experiments that measured RNA/protein ratios of organisms during exponential growth in the same batch of medium containing $\left[{ }^{14} \mathrm{C}\right]$ uracil and $\left[{ }^{3} \mathrm{H}\right]$ lysine are summarized in Fig. 7. The first comparison (Fig. 7a) is of strains A19, R1, R5, $\mathrm{R} 10$ and $\mathrm{R} 15$. The latter three strains grew rather slowly but had 'normal' sedimentation profiles very similar to that of A19. All strains have an RNA/protein ratio proportional to their growth rates (expressed as the reciprocal of their generation times). Fig. $7($ b) compares strains A19 and R15 with revertant strains $R 4, R 8, R 19$ and $R 24$. The latter four strains have RNA/protein ratios up to twice those expected from their growth rates. For example, revertant $R 8$ (mean generation time $90 \mathrm{~min}$ ) has a rather higher RNA content than strain A19 (mean generation time $26 \mathrm{~min}$ ).

\section{DISCUSSION}

In these experiments, mutants dependent on (and resistant to) erythromycin were obtained at a frequency about $0 \cdot 1 \%$ that of resistant organisms. It is difficult to assess whether resistance and dependence in strains such as 103 are conferred by different mutations or a single event. Mutation to streptomycin dependence in $E$. coli is at the same ribosomal protein $(r p s L)$ locus that confers resistance. Similarly, kasugamycin dependence and resistance can simultaneously result from an altered ribosomal protein S9 ( $r p s I$ locus), although in other kasugamycin- (and spectinomycin- and rifampicin-) requiring organisms there are separate mutations for resistance and dependence (Dabbs, 1983). In an erythromycin-dependent strain (Sparling \& Blackman, 1973), the resistance mutation was at about $73 \mathrm{~min}$ and so probably in ery $A$ or ery $B$. (These loci are synonymous with $r p l D$ and $r p l V$ respectively, which specify ribosomal proteins L4 and L22: Bachmann, 1983.) The dependence mutation, mac, was separate and at about $26 \mathrm{~min}$. mac is not near any gene that specifies a ribosomal protein, although, as pointed out by Dabbs (1986), an antibiotic dependence that is suppressed by a series of ribosomal mutations is not itself necessarily ribosomal. Against this background, the status of the altered ribosomal protein L25 in the erythromycin-dependent strain 103 is uncertain. The gene $(r p l Y)$ for L25 is at $47 \mathrm{~min}$; an 
alteration could cause the resistance, dependence, or both, or be adventitious and result from the mutagenesis with NTG. Transfer of the alteration to a different genetic background should resolve these questions. The reversions of strain 103 to independence were spontaneous events so that in these cases the additional alterations to ribosomal proteins are very likely to be responsible for the new phenotypes.

Revertant strain R1 has a less basic protein L19 than strains A19 or 103 and also has 70S ribosomes that readily dissociate into ribosomal sub-units during centrifuging. Dissociation would be enhanced if binding of $\mathrm{Mg}^{2+}$ to $70 \mathrm{~S}$ ribosomes were reduced or, more likely, if there were a greater than usual decrease in molar volume when $70 \mathrm{~S}$ ribosomes dissociate to sub-units (Pande \& Wishnia, 1986). Similar but less pronounced effects were noted in some kasugamycinresistant strains of $E$. coli (Poldermans et al., 1980), whose $70 \mathrm{~S}$ ribosomes were more prone to dissociate than those from sensitive organisms. Kasugamycin resistance arises from failure to methylate adjacent adenosines near the $3^{\prime}$ end of $16 \mathrm{~S}$ rRNA. This might directly affect sub-unit association if the RNAs of the ribosomal sub-units are in direct contact (Yusupov \& Spirin, 1986). Protein L19 has been located at the base of the 50S sub-unit facing the small sub-unit (Stöffler et al., 1984) and is thus at the sub-unit interface. The binding of L19-specific antibodies to $50 \mathrm{~S}$ ribosomes prevents their association with $30 \mathrm{~S}$ ribosomes (Noll et al., 1976). Thus altered L19 might affect sub-unit association directly through interaction with proteins (or the RNA) of the smaller sub-unit or indirectly by causing conformational rearrangements in 23S rRNA. Stöffler et al. (1984) reported that a strain (AM149) that lacked protein L19 had 70S ribosomes of normal stability. They suggested either that L19 played no essential role in sub-unit association or that the other mutations in strain AM149 compensated for the absence of this protein. In strain R1, an altered L19 does have a marked effect on ribosome stability; here other ribosome mutation(s) present may either fail to influence or even enhance the effect. Transfer of the L19 mutations to other backgrounds should resolve these possibilities.

Similar considerations apply to strain R8, whose 70 S ribosomes are also pressure-sensitive and in which protein $\mathrm{L} 19$ is either absent or much altered. In addition, strain R8 has defects in ribosome assembly. The experiments suggest that the material in extracts that co-sediments with either $30 \mathrm{~S}$ or $50 \mathrm{~S}$ ribosomal sub-units comprises roughly equal proportions of 'genuine' sub-units and precursor particles. A similar situation may exist with strain R24 (lacking protein L1). Strain R8 thus also differs from mutant AM149 (Stöffler et al., 1984), which lacks protein L19 and where there was no evidence for an assembly defect. The genetic background of the various strains may again be responsible for these differences.

Strain R8 grows at about a third the rate of the parent strain A19 yet has a similar RNA content. Indeed, oversynthesis of RNA seems to be diagnostic of revertants to erythromycin independence with altered ribosome assembly. It is found also in strain R24 and in strain R19, whose sedimentation profile shows substantial accumulation of a putative precursor to $50 \mathrm{~S}$ ribosomal sub-units. Revertant strain R4, which lacks protein S20, accumulates material that, from its sedimentation coefficient and kinetic properties, is a precursor to $30 \mathrm{~S}$ ribosomal subunits.

It is difficult to rationalize effects on RNA content and ribosome synthesis in terms of regulatory properties of the ribosomal proteins that are absent or altered. Oversynthesis of RNA is not universal among revertants to erythromycin independence. Nor is it inevitable in revertants that lack ribosomal proteins. Unpublished work (by B. A. Maguire \& D. G. Wild) has noted that strains AM90 or AM108 (Dabbs, 1979), without proteins L28, or L28 plus L33 respectively, have virtually normal RNA contents and sedimentation profiles. This contrasts with strain TP28 (see Introduction), which synthesizes L28 and L33 at half the normal rate, oversynthesizes RNA and accumulates a precursor to 50 S ribosomes (Butler \& Wild, 1984, 1985). Regulation of the L28-L33 transcription unit has not been investigated. Protein S20 (absent from strain R4) regulates its own translation. Similarly, protein L1 (missing from strain R24) is the regulatory protein of the unit that comprises genes for L11 and L1. However, neither protein L19 (whose gene is distal in the 'S16' operon) nor protein L24 has had regulatory properties ascribed to it, although the absence of protein L24 elevates rates of synthesis of about four other ribosomal proteins from scattered transcription units (Dabbs, 1984). 
A more general explanation of oversynthesis of RNA can be based on the ribosome feedback regulation model of Nomura et al. (1984). This proposes that synthesis of rRNA and tRNA (and perhaps the transcription of ribosomal protein genes) is negatively regulated by products of rRNA operons that are not the rRNAs themselves but may be non-translating ribosomes in the cellular pool. In conformity with this, Takebe et al. (1985) found that overproduction of protein S4 not only inhibited translation from its own ('alpha') operon and therefore ribosome assembly but stimulated RNA synthesis. This was seen as a consequence of a decreased number of free ribosomes. Failure to make a ribosomal protein, as found in some revertants from erythromycin dependence, is thus partially equivalent to inhibition of ribosomal protein synthesis. However, strain R8 (and possibly strain R24) accumulates ribosomal sub-units as well as precursor particles so that the situations are not completely comparable. The ribosome feedback model does not specify the mivlecular mechanism involved in regulation and it is not yet clear to what extent this system is independent of that responsible for 'stringent control'. Here, the synthesis of rRNA and tRNA is shut off during amino acid starvation, most likely by the inhibition of transcription from 'stringent' promoters by the guanosine tetraphosphate (ppGpp) produced by ribosomes in an idling reaction (Lindahl \& Zengel, 1986). RNA synthesis in strain TP28 (which over-produces RNA during exponential growth) remains under stringent control. This suggests that mechanisms for stringency and growth-rate control of RNA content are separable (Butler $e t$ al., 1985). Even so, strains that have reverted to erythromycin independence and oversynthesize RNA might have ribosomes that produce $\mathrm{ppGpp}$ poorly. Alternatively, growth-rate control may be manipulated through some other property of free ribosomes or sub-units that is faulty in these revertants. These possibilities remain to be investigated.

Some experiments were done by Dr Peter Butler or Mr Michael Butlin. All were done with excellent technical assistance from Mr Jean Rotsaert.

\section{REFERENCES}

BaChManN, B. J. (1983). Linkage map of Escherichia coli K-12, edition 7. Microbiological Reviews 47, 180-230.

Barritault, D., Expert-Bezancon, A., Guerin, M.-F. \& HAYES, D. (1976). The use of acetone precipitation in the isolation of ribosomal proteins. European Journal of Biochemistry 63, 131-135.

Butler, P. D. \& WiLD, D. G. (1984). Ribosomal protein synthesis by a mutant of Escherichia coli. European Journal of Biochemistry 144, 649-654.

BUTLER, P. D. \& WILD, D. G. (1985). The location of a mutation affecting ribosomal protein synthesis by Escherichia coli. Journal of General Microbiology 131, 135-144.

Butler, P. D., Sims, P. F. G. \& Wild, D. G. (1980). Intermediates in the assembly of ribosomes by a mutant of Escherichia coli. Biochemical Journal 190, 157-170.

Butler, P. D., Cattaneo, E. \& Wild, D. G. (1985). Interactions between mutations affecting ribosome synthesis in Escherichia coli. Journal of General Microbiology 131, 945-949.

CUNDLIFFE, E. (1986). Involvement of specific portions of ribosomal RNA in defined ribosomal functions: a study utilizing antibiotics. In Structure, Function and Genetics of Ribosomes, pp. 586-604. Edited by B. Hardesty \& G. Kramer. Berlin: Springer-Verlag.

DabBS, E. R. (1979). Selection for Escherichia coli mutants with proteins missing from the ribosome. Journal of Bacteriology 140, 734-737.

DABBS, E. R. (1983). Escherichia coli kasugamycin dependence arising from mutation at the rpsI locus. Journal of Bacteriology 153, 709-715.
DABBs, E. R. (1984). Organization and regulation of ribosomal protein genes in bacteria. In Genetics: New Frontiers (Proceedings of the International Congress of Genetics, 1983), pp. 35-48. New Delhi: Oxford and IBH Publishing.

DABBS, E. R. (1986). Mutant studies on the prokaryotic ribosome. In Structure, Function and Genetics of Ribosomes, pp. 733-748. Edited by B. Hardesty \& G. Kramer. Berlin: Springer-Verlag.

Dabbs, E. R., EHRlich, R., Hasenbank, R., SCHROETER, B.-H., StÖFFleR-MeILICKE, M. \& STÖFfLER, G. (1981). Mutants of Escherichia coli lacking ribosomal protein L1. Journal of Molecular Biology 149, 553-578.

EHRENBERG, M., ANDERSSON, D., BOHMAN, K., Jelenc, P., Ruusala, T. \& Kurland, C. G. (1986). Ribosomal proteins tune rate and accuracy in translation. In Structure, Function and Genetics of Ribosomes, pp. 573-585. Edited by B. Hardesty \& G. Kramer. Berlin: Springer-Verlag.

GeSTELAND, R. F. (1966). Isolation and characterization of ribonuclease I mutants of Escherichia coli. Journal of Molecular Biology 16, 67-84.

HARDY, S. J. S. (1975). The stoichiometry of the ribosomal proteins of Escherichia coli. Molecular and General Genetics 14, 253-274.

Herold, M., Nowotny, V., Dabbs, E. R. \& NierHaUs, K. H. (1986). Assembly analysis of ribosomes from a mutant lacking the assembly-initiator protein L24: lack of L24 induces temperature sensitivity. Molecular and General Genetics 203, 281-287.

KenNy, J. W., LAMbert, J. M. \& TRAUT, R. R. (1979). Cross-linking of ribosomes using 2-iminothiolane 
(methyl 4-mercaptobutyrimidate) and identification of cross-linked proteins by diagonal polyacrylamide/ sodium dodecyl sulfate gel electrophoresis. Methods in Enzymology 59, 534-550.

LINDAHL, L. \& ZENGEL, J. M. (1986). Ribosomal genes in Escherichia coli. Annual Review of Genetics 20, 297-326.

Madjar, J.-J., Michel, S., Cozzone, A. J. \& Reboud, J.-P. (1979). A method to identify individual proteins in four different two-dimensional gel electrophoresis systems: application to Escherichia coli ribosomal proteins. Analytical Biochemistry 92, 174-192.

MARKeY, F. \& WILD, D. G. (1976). An unusual precursor of 50S ribosomes in a mutant of Escherichia coli. Biochemical Journal 158, 451-456.

MoAzed, D. \& Noller, H. F. (1987). Interaction of antibiotics with functional sites in $16 \mathrm{~S}$ ribosomal RNA. Nature, London 327, 389-394.

Nishi, K., DabBs, E. R. \& SCHNIER, J. (1985). DNA sequence and complementation analysis of a mutation in the $r p l X$ gene from Escherichia coli leading to loss of ribosomal protein L24. Journal of Bacteriology 163, 890-894.

Noll, M., Stöffler, G. \& Highland, J. H. (1976). Dissociation of Escherichia coli ribosomes into active sub-units. Journal of Molecular Biology 108, 259-264.

Nomura, M., Gourse, R. \& Baughman, G. (1984). Regulation of the synthesis of ribosomes and ribosomal components. Annual Review of Biochemistry 53, 75-117.

Nowotny, V. \& Nierhaus, K. H. (1982). Initiator proteins for the assembly of the 50S sub-unit from Escherichia coli ribosomes. Proceedings of the National Academy of Sciences of the United States of America 79, 7238-7242.

Pande, C. \& Wishnia, A. (1986). Pressure dependence of equilibria and kinetics of Escherichia coli ribo- somal sub-unit association. Journal of Biological Chemistry 261, 6272-6278.

Poldermans, B., Bakker, H. \& Van KnipPenberg, P. H. (1980). Studies on the function of two adjacent $N^{6}, N^{6}$-dimethyladenosines near the $3^{\prime}$ end of $16 \mathrm{~S}$ ribosomal RNA of Escherichia coli. IV. The effect of the methyl groups on ribosomal sub-unit interaction. Nucleic Acids Research 8, 143-151.

Sparling, P. F. \& Blackman, E. (1973). Mutation to erythromycin dependence in Escherichia coli K12. Journal of Bacteriology 116, 74-83.

Stöffler, G., NoAH, M., StöFfler-Meilicke, M. \& DABBS, E. R. (1984). The localization of protein L19 on the surface of $50 \mathrm{~S}$ sub-units of Escherichia coli aided by the use of mutants lacking protein L19. Journal of Biological Chemistry 259, 4521-4526.

Subramanian, A. R. \& Dabbs, E. R. (1980). Functional studies on ribosomes lacking protein $\mathrm{Ll}$ from mutant Escherichia coli. European Journal of Biochemistry 112, 425-430.

Takebe, Y., Miura, A., Bedwell, D. M., Tam, M. \& NoMURA, M. (1985). Increased expression of ribosomal genes during inhibition of ribosome assembly in Escherichia coli. Journal of Molecular Biology 184, 23-30.

WittmanN, H. G. (1986). Structure of ribosomes. In Structure, Function and Genetics of Ribosomes, pp. 1-27. Edited by B. Hardesty \& G. Kramer. Berlin : Springer-Verlag.

YuSUPOV, M. M. \& SPIRIN, A. S. (1986). Are there proteins between the ribosomal sub-units? Hot tritium bombardment experiments. FEBS Letters 197, 229-233.

ZAmir, A., Miskin, R., Vogel, Z. \& Elson, D. (1974). The inactivation and reactivation of Escherichia coli ribosomes. Methods in Enzymology 30, 406-426. 